\title{
Numerical optimization of gene electrotransfer into muscle tissue
}

\author{
Anze Zupanic, Selma Corovic, Damijan Miklavcic, Mojca Pavlin ${ }^{*}$
}

\footnotetext{
* Correspondence: mojca.pavlin@fe. uni-lj.si

University of Ljubljana, Faculty of Electrical Engineering, Trzaska cesta 25. SI-1000 Ljubljana, Slovenia
}

\begin{abstract}
Background: Electroporation-based gene therapy and DNA vaccination are promising medical applications that depend on transfer of pDNA into target tissues with use of electric pulses. Gene electrotransfer efficiency depends on electrode configuration and electric pulse parameters, which determine the electric field distribution. Numerical modeling represents a fast and convenient method for optimization of gene electrotransfer parameters. We used numerical modeling, parameterization and numerical optimization to determine the optimum parameters for gene electrotransfer in muscle tissue.
\end{abstract}

Methods: We built a 3D geometry of muscle tissue with two or six needle electrodes (two rows of three needle electrodes) inserted. We performed a parametric study and optimization based on a genetic algorithm to analyze the effects of distances between the electrodes, depth of insertion, orientation of electrodes with respect to muscle fibers and applied voltage on the electric field distribution. The quality of solutions were evaluated in terms of volumes of reversibly (desired) and irreversibly (undesired) electroporated muscle tissue and total electric current through the tissue.

Results: Large volumes of reversibly electroporated muscle with relatively little damage can be achieved by using large distances between electrodes and large electrode insertion depths. Orienting the electrodes perpendicular to muscle fibers is significantly better than the parallel orientation for six needle electrodes, while for two electrodes the effect of orientation is not so pronounced. For each set of geometrical parameters, the window of optimal voltages is quite narrow, with lower voltages resulting in low volumes of reversibly electroporated tissue and higher voltages in high volumes of irreversibly electroporated tissue. Furthermore, we determined which applied voltages are needed to achieve the optimal field distribution for different distances between electrodes.

Conclusion: The presented numerical study of gene electrotransfer is the first that demonstrates optimization of parameters for gene electrotransfer on tissue level. Our method of modeling and optimization is generic and can be applied to different electrode configurations, pulsing protocols and different tissues. Such numerical models, together with knowledge of tissue properties can provide useful guidelines for researchers and physicians in selecting optimal parameters for in vivo gene electrotransfer, thus reducing the number of animals used in studies of gene therapy and DNA vaccination. 


\section{Background}

In the last decades advances in genetic research offered a set of new therapies for various diseases based on in vivo genetic manipulations. The most developed of them are gene therapy and DNA vaccination, which have already been tested in several clinical trials [1-4]. While gene therapy works by delivering therapeutic genes into target cells to express themselves and produce proteins acting directly against a given disease, in genetic vaccination the produced proteins act as antigens that illicit an immune response [5,6]. In the future, genetic therapies could represent an effective treatment for degenerative diseases, cancer, infections and cardiovascular diseases, for which currently no adequate treatments are available [3,7-10].

The first step for gene therapy and DNA vaccination is efficient transfer of DNA molecules into target cells. In vitro, chemical, physical and biological methods have been successfully used for gene transfer $[7,11,12]$. However, there have been difficulties of translating these methods into in vivo settings. Currently, viral vectors boast the highest transfection efficiency, but this efficiency comes with an increased risk of viral infection [13,14]. Therefore, alternative methods are being developed. One of the most promising physical methods for gene transfer in vivo is gene electrotransfer which, in comparison to viral vectors, is not hampered in terms of immunogenicity or pathogenicity. Gene electrotransfer combines the use of pDNA and local application of electric pulses, which increase the permeability of target cells (electroporation) for different molecules, including pDNA, and thus enable transfer of DNA into the cell. Compared to other physical and chemical methods, it was shown that gene electrotransfer is the most versatile and also the most efficient method in vivo compared to other methods. For example, the gene gun method is limited to exposed tissues while complexes of DNA and cationic lipids or polymers can be unstable, inflammatory and toxic [7]. Gene electrotransfer has therefore great potential to be used in clinics for treatment of cancer and various chronic diseases [15-22], and also for DNA vaccination for prevention of various infectious diseases and HIV [6]. Moreover, recently it was demonstrated that gene electrotransfer can be successfully applied as a method for DNA vaccination for cancer treatment $[6,23,24]$, where DNA for a certain tumor antigen is transferred during remission and can thus prepare the immune system for a better response against the tumor cells during relapse of the disease.

Gene electrotransfer was demonstrated almost 30 years ago [25] when it was first shown that exposing cells to high-voltage electric pulses results in transfer of DNA molecules and expression of the delivered genes. Up to now, several steps that are involved in gene electrotransfer have been identified: electropermeabilization of the cell membrane, contact of pDNA with the cell membrane (formation of a DNA-membrane complex), translocation of pDNA across the membrane, transfer of pDNA to and into the nucleus and gene expression [26-29]. The effectiveness of electroporation and consequently of gene electrotransfer depends on pulse parameters, such as amplitude, duration, number, pulse repetition frequency and geometric properties of electrode and tissue/sample configuration [30-33]. These parameters define the duration of exposure to external electric field and the electric field strength, which have been shown to be the most important parameters in cell electroporation. Namely, molecular transport into and out of cells is observed only above a threshold value for reversible electroporation $E>E_{\text {rev }}$. When electric field is further increased above the irreversible 
electroporation threshold $E>E_{i r r}$ (or when longer and/or several pulses are used) the changes in the cell membrane become irreversible and cells die. Therefore for efficient gene electrotransfer it is crucial to choose an appropriate applied voltage/electrode configuration, such that the local electric field in the target tissue is between the reversible and irreversible electroporation threshold $E_{r e v}>E>E_{i r r}$, which enables gene transfer and preserves cell viability, thus enabling successful gene expression.

Gene electrotransfer was first demonstrated in vivo in 1998 by several independent studies [34-37]. It is currently being extensively studied on animal models in vivo for gene therapy $[7,16,19,30,38,39]$ as well as DNA vaccination $[6,23,40]$. In the last years the first human clinical trials have also started and also show encouraging results $[18,19,41-43]$. One of the major obstacles towards translating gene electrotransfer into clinical applications is its relatively low efficiency. Even though it was demonstrated that in skin [39,44-50] and muscle tissue [34,37,51-56] prolonged expression of transfected genes can be achieved, the relative transfection rates have remained relatively low. In order to improve transfection efficiency the parameters of electric pulses have to be optimized depending on the type of electrodes used and specifically adjusted for each target tissue (e.g. muscle, skin, tumor tissue).

Several researchers have demonstrated that numerical modeling can be used to predict the extent of electroporation in biological tissues [57-64]. Also, numerical modeling and optimization have already been used for optimization of electric pulse parameters for electrochemotherapy of subcutaneous tumors, for tumor ablation with irreversible electroporation [63,65-67] and recently, the first deep-seated tumor was treated with electrochemotherapy based on a numerical treatment plan [68]. However, up to now there exists no such study which would use numerical modeling for optimization of gene electrotransfer.

In our present study we used 3D numerical modeling and numerical optimization to determine the best electrical parameters for efficient gene electrotransfer into muscle tissue, which is regarded by many as the "tissue of choice" for gene electrotransferbased gene therapy and DNA vaccination [19,30,41,69,70]. We performed a parametric study to better understand how various electroporation parameters (applied voltage, number of electrodes used, electrode positions, insertion depth) affect the electric field distribution in muscle tissue, and numerical optimization of the parameters to demonstrate that such numerical "treatment planning" could be used by researchers and clinicians to better control the extent of electroporation in the target tissues. We compared different needle electrode configurations recommended in the literature for gene electrotransfer in large animals and humans and analyzed the effect of orientation of the electrodes (and thus the electric field) with respect to the orientation of muscle fibers. The methods used in this study and the obtained results can be used as guidelines for future numerical studies and planning of gene electrotransfer in vivo.

\section{Methods}

\section{Model geometry and tissue properties}

The numerical model of electroporation used in our study was similar to the one used by Corovic et al for modeling electroporation of muscle tissue in small animals [71]. In short, muscle tissue geometry was modeled as a block of size $10 \times 10 \times 6 \mathrm{~cm}$ in the direction of the $\mathrm{X}, \mathrm{Y}$ and $\mathrm{Z}$ axis, respectively (Figure 1), with the long axis of the muscle 


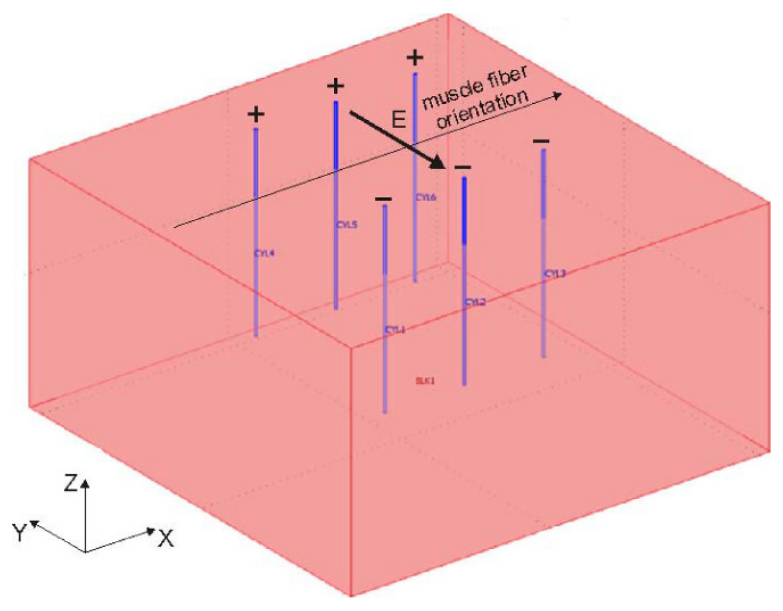

Figure 1 Model geometry with muscle tissue (pink) and needle electrodes (blue).

fibers aligned with the $x$ axis. The size chosen is similar to the size of a larger human muscle and at the same time represents a sufficiently large computational domain to avoid any significant numerical errors due to boundary conditions. Two different needle electrode configurations were used in our model: two needle electrodes and six needle electrodes arranged into two rows of three electrodes (Figure 1). The needle electrodes were modeled as $5 \mathrm{~cm}$ long stainless steel cylinders with diameters of $0.7 \mathrm{~mm}$.

The muscle tissue was considered anisotropic, with higher conductivity in the direction parallel to muscle fibers $\left(\sigma_{x x}^{1}=0.75 \mathrm{~S} / \mathrm{m} ; \sigma_{x x}^{2}=2.0 \mathrm{~S} / \mathrm{m}\right)$ than in the perpendicular direction $\left(\sigma_{y y}^{1}=\sigma_{z z}^{1}=0.135 \mathrm{~S} / \mathrm{m} ; \sigma_{y y}^{2}=\sigma_{z z}^{2}=0.54 \mathrm{~S} / \mathrm{m}\right)$. Index ${ }^{1}$ denotes initial values prior to electroporation, while index ${ }^{2}$ denotes the maximum achieved conductivities in the model (after irreversible electroporation is achieved in the tissue) [72]. The reversible electroporation threshold values for muscle tissue were taken to be 80 $\mathrm{V} / \mathrm{cm}$ and $200 \mathrm{~V} / \mathrm{cm}$ for electric field parallel and perpendicular to muscle fiber orientation, respectively, while the irreversible threshold was taken to be $450 \mathrm{~V} / \mathrm{cm}$ irrespective of electric field direction. These values were selected considering both our previous studies of in vivo electroporation studies [71,73], where the thresholds were measured for $8 \times 100 \mu$ s electric pulses, and the measurements of muscle tissue conductivity found in the available literature [74]. The importance of using anisotropic tissue properties instead of isotropic properties is illustrated in Figure 2, where the difference in electric field distribution between both cases is clearly seen.

\section{Numerical modeling}

The numerical models were designed in Comsol Multiphysics 3.5a (Comsol AB, Sweden) and solved with the finite element method on a desktop PC (Windows 7 64bit, Intel Core 2 Duo $2.66 \mathrm{GHz}, 4$ GB RAM). The electric field distribution was determined by solving the Laplace equation for static electric currents:

$$
\nabla(\sigma(-\nabla u))=0
$$

where $\sigma$ is the tensor of electrical conductivity and $u$ the electric potential. The boundary conditions used in our calculations were: 1) constant potential on the surface 


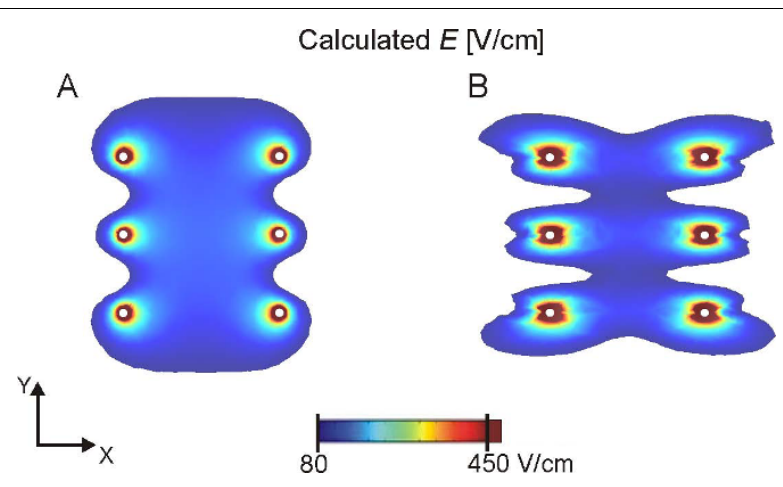

Figure 2 Electric field distribution for isotropic and anisotropic muscle conductivity. Electric field distribution for six needle electrodes (white circles) with a) isotropic tissue and b) anisotropic tissue properties is shown. Electric field between $80 \mathrm{~V} / \mathrm{cm}$ and $450 \mathrm{~V} / \mathrm{cm}$ are presented in colors from blue to red, while fields over $450 \mathrm{~V} / \mathrm{cm}$ are presented in dark brown (around the electrodes).

of the active parts of the electrodes and 2) insulation $(\boldsymbol{n} \cdot \boldsymbol{J}=0)$ on the outer boundaries of the model.

As the parametric study and optimization described in the next section involved moving and rotating the electrodes with respect to the muscle tissue and thus repeated meshing of the model geometry, some of the meshing could be avoided by rotating the tissue properties (thus virtually rotating the muscle tissue) instead of the electrodes. The final form of the conductivity used in the models is therefore given by a tensor:

$$
\sigma=\left(\begin{array}{ccc}
\sigma_{x x} \sin ^{2} \phi+\sigma_{y y} \cos ^{2} \phi & \left|\sigma_{x x}-\sigma_{y y}\right| \sin \phi \cos \phi & 0 \\
\left|\sigma_{x x}-\sigma_{y y}\right| \sin \phi \cos \phi & \sigma_{y y} \sin ^{2} \phi+\sigma_{x x} \cos ^{2} & 0 \\
0 & 0 & \sigma_{z z}
\end{array}\right)
$$

Since tissue properties are known to change during electroporation [72,75,76], each component $\left(\sigma_{x x}\right.$ and $\sigma_{y y}=\sigma_{z z}$ ) of electrical conductivity was modeled as an electric field-dependent function $\sigma(E)$ :

$$
\sigma(E)=\frac{\sigma_{2}-\sigma_{1}}{E_{\text {irr }}-E_{\text {rev }}} \cdot E+\sigma_{1}
$$

where $\sigma_{1}$ and $\sigma_{2}$ are tensors of electrical conductivities of non-electroporated and electroporated tissues, respectively (see previous section), and $E_{i r r}$ and $E_{r e v}$ are the thresholds of irreversible and reversible electroporation, respectively. We approximated the dynamics of the conductivity changes during electroporation by performing several sequential calculation of the electric field distribution, while changing the conductivities according to Eq. 3. The details of the sequential analysis can be found in our previous work $[57,73]$.

The results of the numerical modeling were analyzed by calculating the volumes for reversibly and irreversibly electroporated muscle tissue, $V_{\text {rev }}$ and $V_{\text {irr }}$, respectively, and total current through the tissue $I$. $V_{\text {rev }}$ was calculated by integrating the volume of muscle tissue, where conductivity has changed $\left(\sigma_{x x}, \sigma_{y y}\right.$ or $\left.\sigma_{z z}\right)$, while $V_{i r r}$ by integrating the volume, where the electric field was over the irreversible electroporation threshold $E>E_{\text {irr }}$. 


\section{Parametric study}

To determine the best electrode positions and voltages between electrodes for gene electrotransfer into muscle tissue several geometrical and electrical parameters were analyzed in a parametric study. Bound constraints for each parameter and discretization steps were chosen as following: distance between electrodes of different polarity - $d$ (4 $\mathrm{mm}$ and 8-56 mm, $8 \mathrm{~mm}$ step); distance between electrodes of the same polarity - $b$ (4$28 \mathrm{~mm}$, step of $4 \mathrm{~mm})$; depth of electrode insertion $-z(10-40 \mathrm{~mm} ; 10 \mathrm{~mm}$ step); angle between the electric field and muscle fiber orientation $-\varphi\left(0-90^{\circ} ; 22.5^{\circ}\right.$ steps $)$ and voltage between the electrodes - $U(400-2400 \mathrm{~V}, 200 \mathrm{~V}$ step for six electrodes; $600-3000 \mathrm{~V}$ for two electrodes) (Figure 3). Altogether 12,320 calculations were performed for six electrodes and 2,080 for two electrodes. The ranges of geometric parameters were selected to scale from typical dimensions used for gene electrotransfer in small animals to dimension applicable to large animals and humans. Results were controlled for numerical errors by increasing the size of our model domain and increasing the mesh density, until error due to domain size and due to meshing irregularities were insignificant-a further increase in domain size or mesh density only increased the computation time; however, the results $\left(V_{\text {rev }}, V_{\text {irr }}\right)$ changed less than $2 \%$. The quality of solutions for given sets of parameters was evaluated by calculating the volume of muscle tissue that was reversibly but not irreversibly electroporated, and the electric currents flowing through the model, as presented in the objective function:

$$
F=\left\{\begin{array}{cc}
0, & \text { if }\left(V_{\text {irr }}>1 \mathrm{~cm}^{3} \mid I>30 \mathrm{~A}\right) \\
V_{\text {rev }}-V_{\text {irr },} & \text { otherwise }
\end{array}\right\} .
$$

The limit value for $V_{i r r}\left(1 \mathrm{~cm}^{3}\right)$ was based on our estimate of tissue damage produced by electrode insertion and the fact that some tissue damage is always present around needle electrodes during electroporation. The limit value for I (30 A) was based on the limitation of electroporation devices available on the market at the time of the study. By taking into account constraints for $V_{i r r}$ and for $I$, extensive damage to

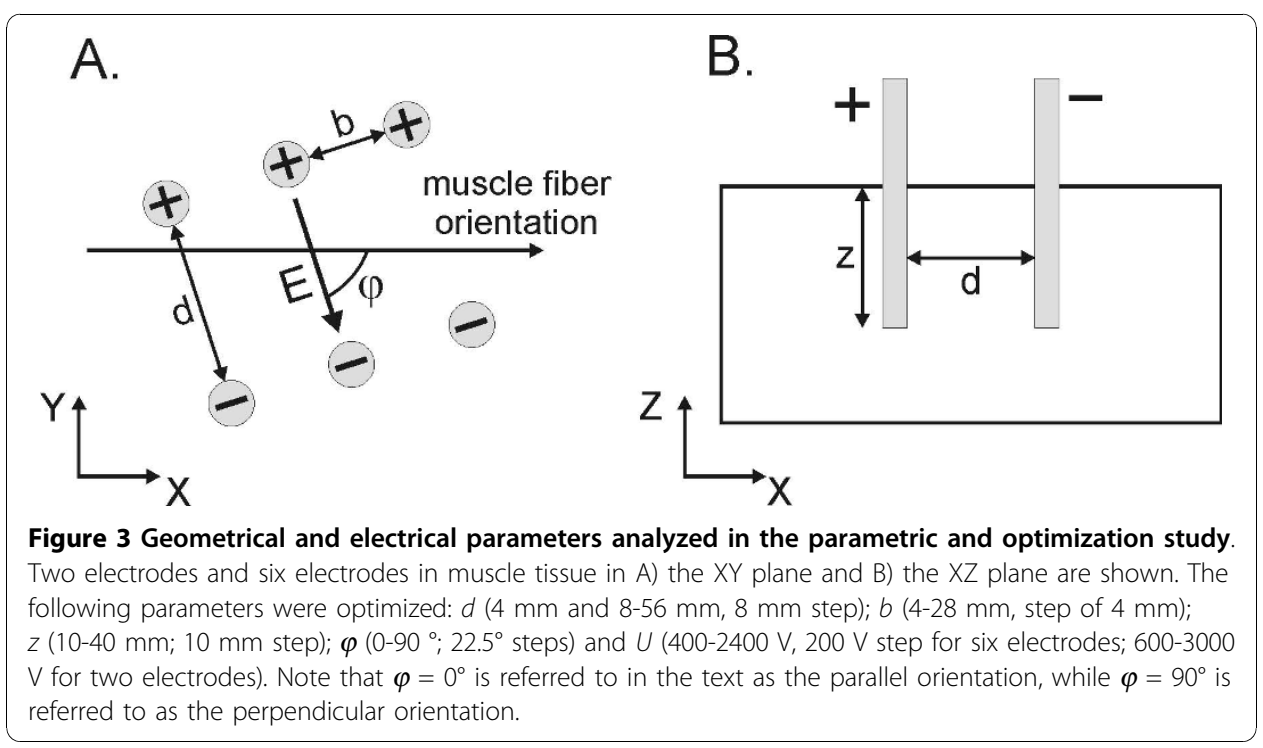


muscle tissue is avoided and compliance with electric pulse generator limitations guaranteed.

\section{Optimization}

The same parameters (distances between electrodes, depth of insertion, voltage between electrodes) and the same objective function used in the parametric study were also used in the optimization, only the steps were smaller: $d-2 \mathrm{~mm}, b-2 \mathrm{~mm}, z-5$ $\mathrm{mm}, \varphi-10^{\circ}$ and $U-100 \mathrm{~V}$. For the optimization we used a genetic algorithm that has been described in detail in our previous work [66]. In short, the genetic algorithm was written in MATLAB 2007a (Mathworks, USA) and run together with the numerical calculation using the link between MATLAB and COMSOL. The initial population of chromosomes (vectors of real numbers - one for each optimized parameter) was generated randomly, taking into account the bound constraints. In each iteration, the chromosomes were selected for reproduction with a probability proportional to the values of their objective function. The selected chromosomes reproduced by mathematical operations of crossover (5) or mutation (6):

$$
\begin{aligned}
& z_{i}=a_{i} \cdot x_{i}+\left(1-a_{i}\right) y_{i}, \quad a_{i} \in[0,1], \\
& m_{i}=x_{i}+b_{i} \cdot x_{i}, \quad b_{i} \in[-0.3,0.3],
\end{aligned}
$$

where $z_{i}$ and $m_{i}$ are child chromosomes, $x_{i}$ and $y_{i}$ are parent chromosomes and $a_{i}$ and $b_{i}$ are numbers randomly chosen from the given intervals. The optimization was stopped after the chromosome with the highest objective function value has not improved in 20 iterations for more than $0.1 \%$, which was interpreted as reaching a solution very close to the global optimum.

\section{Results}

\section{Parametric study}

The parametric study produced a vast number of different solutions of electric field distribution (2,080 for two needle electrodes and 12,320 for six needle electrodes), which were analyzed by calculating the volumes of reversibly and irreversibly electroporated tissue, and the objective function value (Eq. 4). Figures 4, 5, 6 and 7 show the optimal of these solutions (highest $F$ ) for each given value of the analyzed parameter, while all the other parameters change according to the selected bounds and steps (Figure 3). E.g., in Figure 4a for each value of distance between electrodes $d$, all the other parameters $(z, \varphi$, $U$ ) are varied and the optimal solution (highest $F$ ) is presented at given $d$.

\section{Two needle electrodes}

For two needle electrodes, increasing the distance between the electrodes $(d)$ produces higher values of the objective function up to $d=48 \mathrm{~mm}$, however to achieve this, higher voltages have to be used (Figure 4a). In fact, an almost 50-fold increase in the value of objective function is achieved by increasing $d$ from $4 \mathrm{~mm}$ to $48 \mathrm{~mm}$. At $d=$ $56 \mathrm{~mm}$ a significant drop in $F$ was obtained. In Table 1 the optimal parameters for different distances between the electrodes are presented, together with the calculated total current through the model $(I)$ and the volumes of reversibly and irreversibly electroporated tissue $\left(V_{\text {rev }}\right.$ and $\left.V_{\text {irr }}\right)$. 

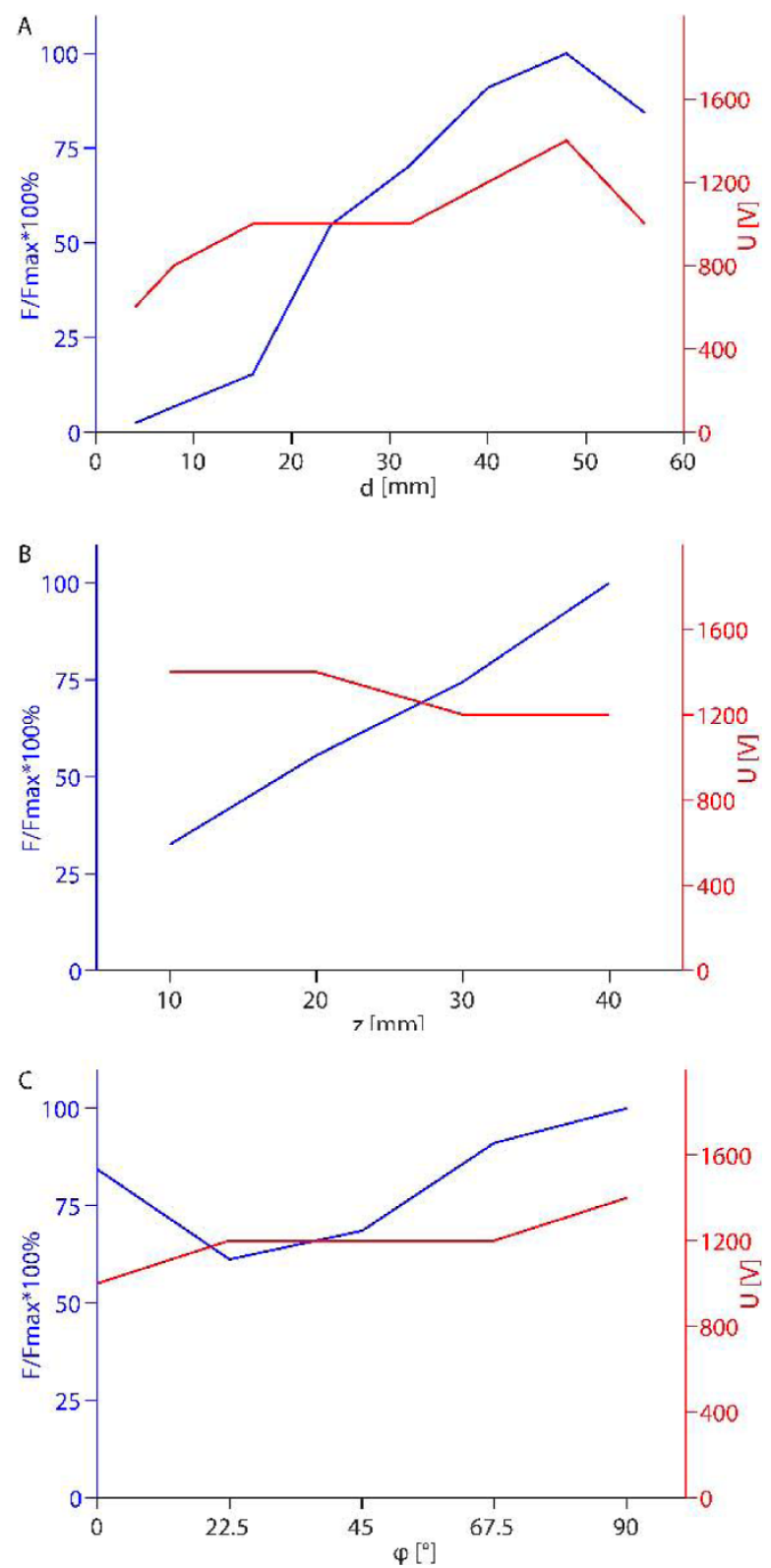

Figure 4 Optimal values of the objective function depending on geometrical parameters for two electrodes. Left axis: maximum values of obtained objective functions normalized by the absolute maximum value of objective function obtained in the parametric study (F/Fmax); right axis: voltage between electrodes $(U)$ that leads to the maximum values. All the figures show optimal solutions for each given value of the parameter shown on the horizontal axis, while the other parameters change in steps as defined in caption of Figure 3 for two electrodes. F/Fmax is presented in dependence of: A) the distance between electrodes $-d, B$ ) depth of electrode insertion $-z$ and $C$ ) angle of electric field with respect to muscle fiber orientation $-\varphi$.

Increasing the depth of insertion $(z)$ also produces higher objective function values, with Figure $4 \mathrm{~b}$ suggesting a linear relationship between the two. Positioning the electrodes so that the electric field is perpendicular to the direction of muscle fibers produces objective functions up to $20 \%$ higher than the parallel orientation (Figure 4c), however slightly higher voltages had to be used to achieve this. 


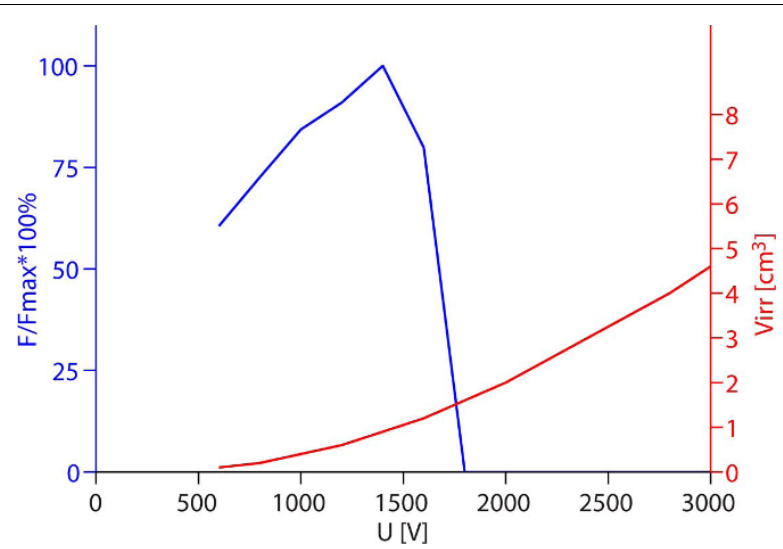

Figure 5 Optimal values of the objective function depending on voltage between electrodes for two electrodes. Left axis: maximum values of obtained objective functions normalized by the absolute maximum value of objective function obtained in the parametric study $\left(F / F_{\max }\right)$; right axis: average volume of irreversible electroporation obtained by using those voltages $\left(V_{\text {irr }}\right)$. The figure shows optimal solutions for given values of $U$, while the other parameters change in steps as defined in caption of Figure 3 for two electrodes.

Figure 5 shows how increasing the voltage between electrodes affects the objective function. At lower voltages increasing the voltage increases the objective function, however after a peak is reached $(1400 \mathrm{~V})$ the objective function values start to sharply decrease, because the damage to tissue exceeds the values $\left(V_{\text {rev }}\right.$ or $\left.I\right)$ tolerated by the objective function.

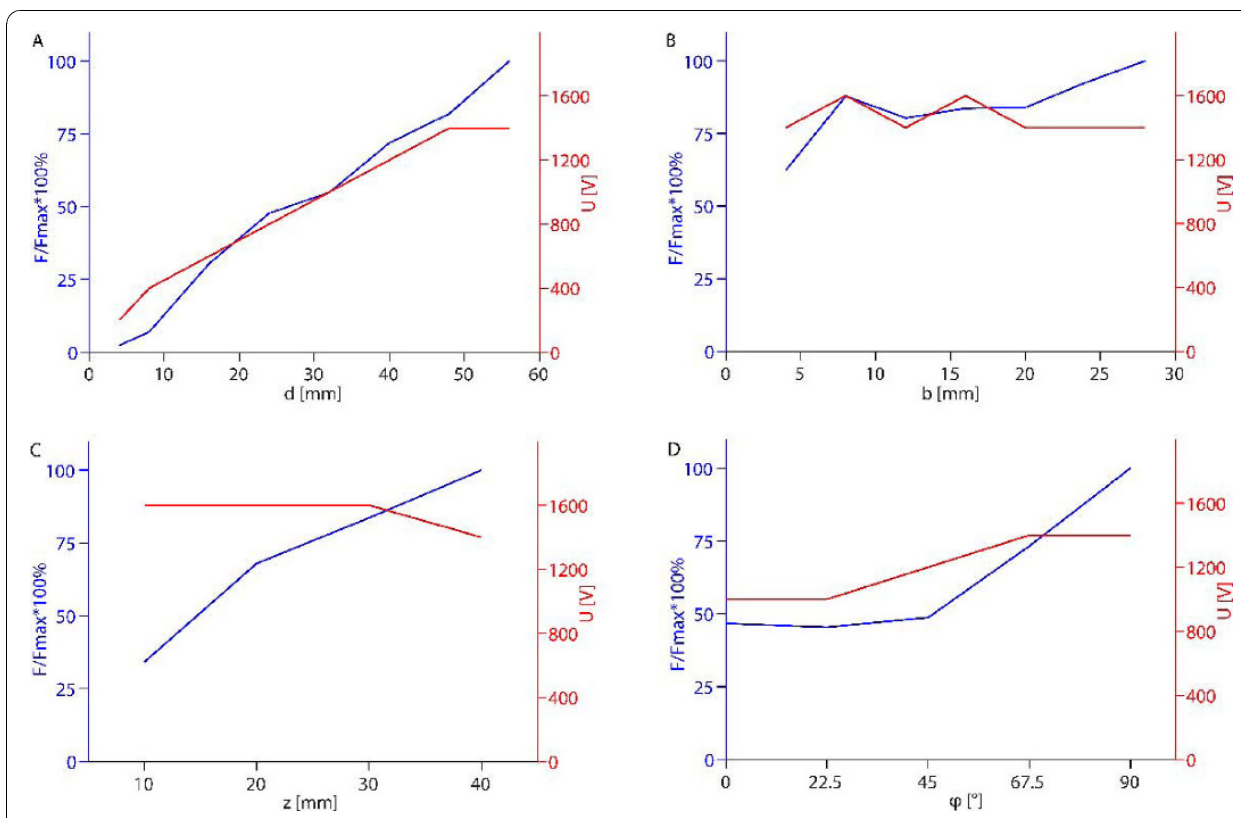

Figure 6 Optimal values of the objective function depending on geometrical parameters for six electrodes. Left axis: maximum values of obtained objective functions normalized by the absolute maximum value of objective function obtained in the parametric study $\left(F / F_{\text {max }}\right)$; right axis: voltages between rows of electrodes $(U)$ that lead to the maximum values. All the figures show optimal solutions for each given value of the parameter shown on the horizontal axis, while the other parameters change in steps as defined in caption of Figure 3 for six electrodes. $F / F_{\text {max }}$ is presented in dependence of: A) the distance between rows of electrodes $-d, B$ ) distance between electrode in a row $-b, C$ ) depth of electrode insertion $-z$ and $D$ ) angle of electric field with respect to muscle fiber orientation - $\varphi$. 


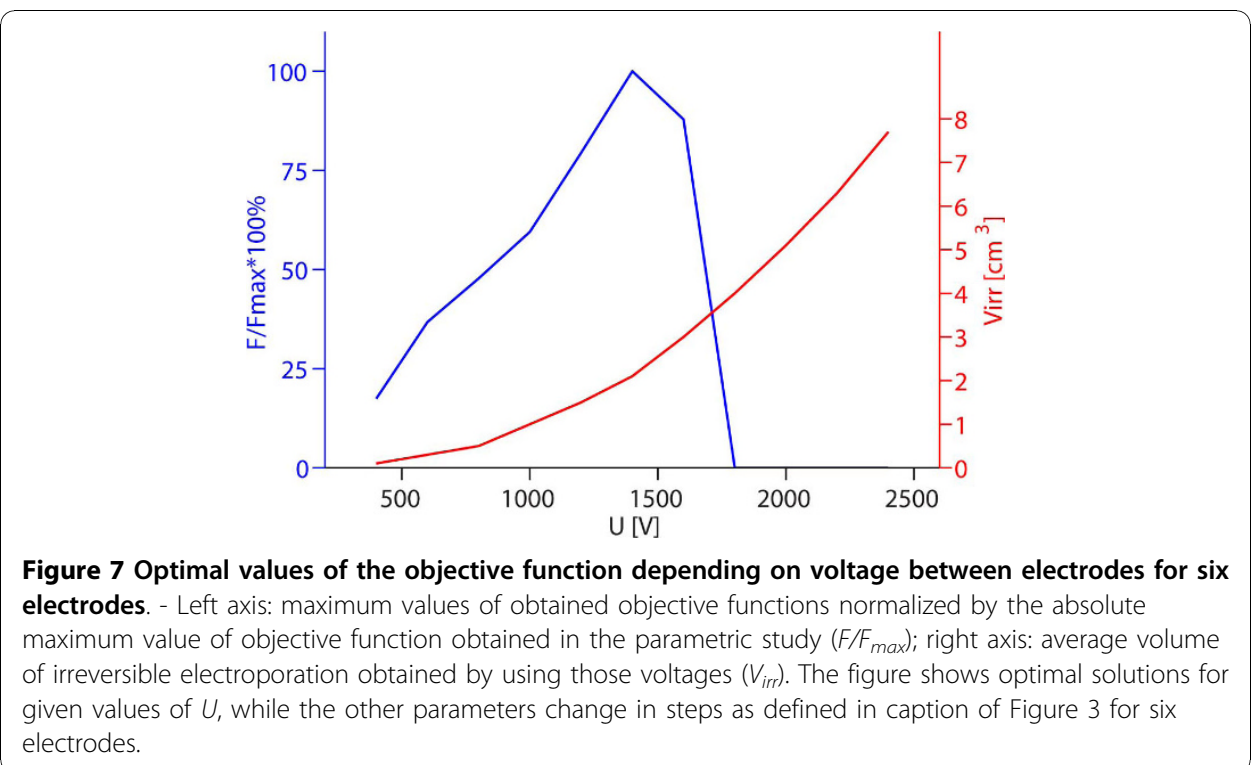

\section{Six needle electrodes}

When we analyzed solutions for six electrodes (Figure 6) similar results were obtained as for two electrodes. Increasing the distances between electrodes and depth of insertion leads to higher values of the objective function and demands higher voltages (Figure $6 \mathrm{a}, \mathrm{c})$. Table 2 shows how changing the distance between the electrode rows affects the other parameters needed to achieve the highest values of the objective function and $V_{\text {rev }}$. Increasing the distance between electrodes in a row $(b)$ also produces some effect, but mainly only between positioning the electrodes very close together or very far apart (Figure 6b). Furthermore, we obtained a significant effect of the electric field orientation on the quality of the solution. Positioning the electrode perpendicularly to the direction of muscle fiber $\left(\varphi=90^{\circ}\right)$ produced solution with twice higher values of the objective function (Figure 6d) compared to parallel orientation of the electrodes $\left(\varphi=0^{\circ}\right)$.

Figure 7 shows how increasing the voltage between the electrode rows affects the objective function: at lower voltages increasing the voltage increases the objective function, however after the maximum is reached $(1400 \mathrm{~V})$ the objective function values sharply decrease.

Table 1 Optimum gene electrotransfer parameters $(z, \varphi, U)$ for two electrodes

\begin{tabular}{ccccccc}
\hline $\boldsymbol{d}[\mathrm{mm}]$ & $\boldsymbol{z}[\mathrm{mm}]$ & $\boldsymbol{\varphi}\left[^{\circ}\right]$ & $\boldsymbol{U}[\mathbf{V}]$ & $\boldsymbol{I}[\mathbf{A}]$ & $\boldsymbol{V}_{\text {rev }}\left[\mathbf{c m}^{\mathbf{3}}\right]$ & $\boldsymbol{V}_{\boldsymbol{i r r}}\left[\mathbf{c m}^{\mathbf{3}}\right]$ \\
\hline 4 & 20 & 90 & 600 & 26.4 & 1.2 & 0.2 \\
8 & 10 & 90 & 800 & 13.0 & 4.4 & 1.0 \\
16 & 30 & 90 & 1000 & 7.5 & 8.7 & 0.9 \\
24 & 40 & 90 & 1000 & 15.0 & 28.7 & 1.0 \\
32 & 40 & 90 & 1000 & 16.6 & 36.2 & 0.7 \\
40 & 40 & 90 & 1200 & 18.4 & 46.9 & 0.8 \\
48 & 40 & 90 & 1400 & 18.4 & 51.5 & 0.9 \\
56 & 40 & 0 & 1000 & 18.9 & 43.4 & 0.8 \\
\hline
\end{tabular}

Calculated values of $I, V_{\text {rev }}, V_{\text {irr }}>$ determined by the parametric study for different distances between electrodes (d). 
Table 2 Optimum gene electrotransfer parameters $(b, z, \varphi, U)$ for six electrodes.

\begin{tabular}{cccccccc}
\hline $\boldsymbol{d}[\mathrm{mm}]$ & $\boldsymbol{b}[\mathrm{mm}]$ & $\boldsymbol{z}[\mathrm{mm}]$ & $\boldsymbol{\varphi}\left[^{\circ}\right]$ & $\boldsymbol{U}[\mathbf{V}]$ & $\boldsymbol{I}[\mathrm{A}]$ & $\boldsymbol{V}_{\text {rev }}\left[\mathrm{cm}^{3}\right]$ & $\boldsymbol{V}_{\boldsymbol{i r r}}\left[\mathrm{cm}^{\mathbf{3}}\right]$ \\
\hline 4 & 8 & 30 & 90 & 200 & 23.3 & 3.7 & 0.1 \\
8 & 24 & 20 & 90 & 400 & 18.1 & 12.0 & 0.1 \\
16 & 24 & 40 & 90 & 600 & 29.6 & 49.0 & 0.8 \\
24 & 24 & 40 & 90 & 800 & 29.9 & 76.5 & 0.8 \\
32 & 16 & 40 & 90 & 1000 & 28.5 & 87.5 & 0.7 \\
40 & 16 & 40 & 90 & 1200 & 29.8 & 114.6 & 0.8 \\
48 & 24 & 30 & 90 & 1400 & 27.4 & 130.6 & 0.9 \\
56 & 28 & 40 & 90 & 1400 & 28.5 & 158.9 & 0.6
\end{tabular}

Calculated values of $I, V_{\text {rev, }}, V_{\text {irr }}$ determined by the parametric study for different distances between electrodes (d).

\section{Optimization}

The optimization results for two electrodes are presented in Figure 8 for 4 sequences of the calculation, taking into account the changes in conductivity during electroporation. The first sequence (Figure 8A), which matches the calculation performed with a static model of electroporation (no changes in conductivity), shows that the beginning of the electric pulse the volume of reversibly electroporation (black contour in

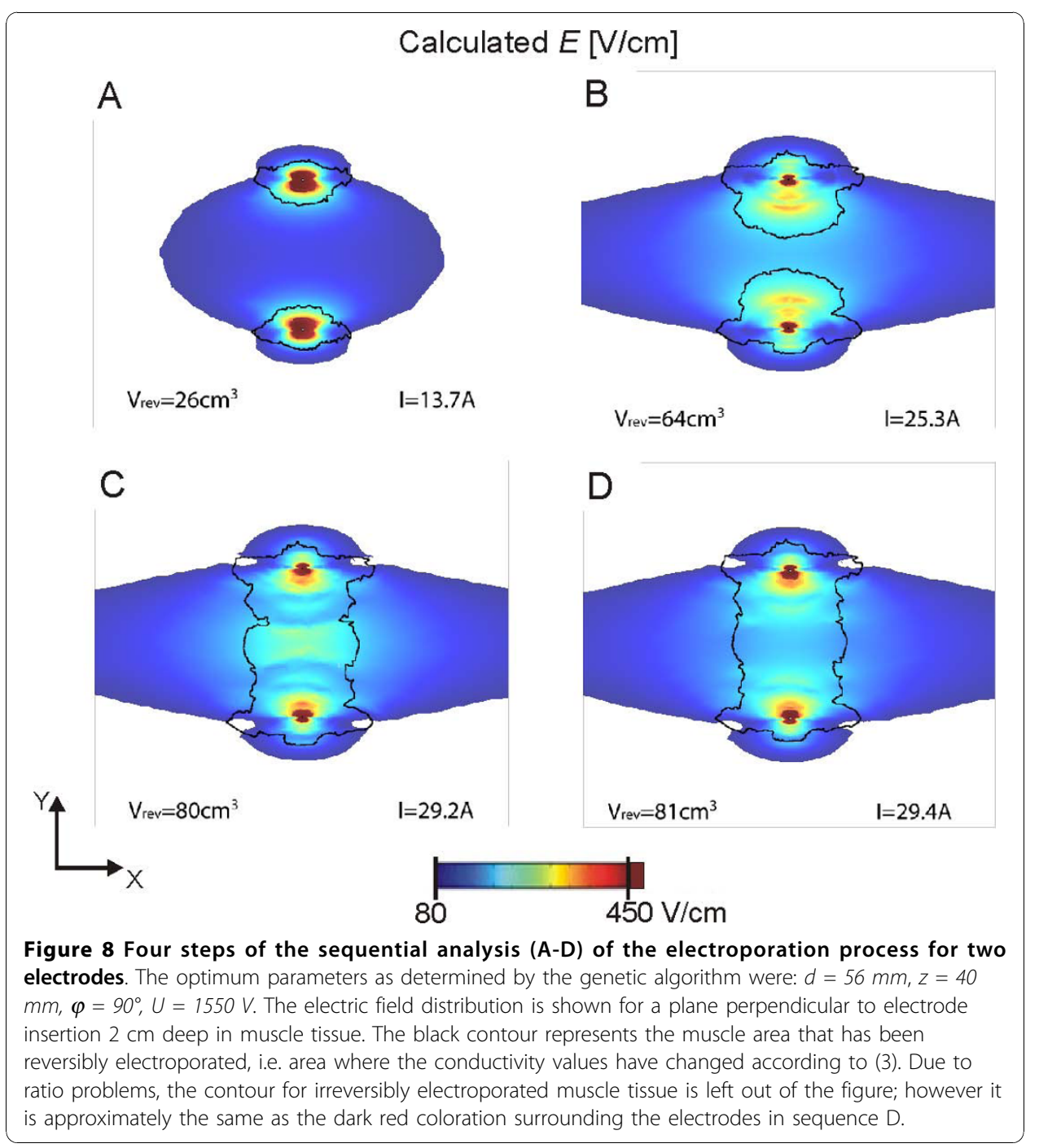


Figures 8, 9 and 10) is mostly located around the electrodes. In the next sequences one can see that the increase of conductivity due to electroporation extends the higher electric fields towards the area in the center between the electrodes, resulting in much larger volumes of reversibly electroporated muscle tissue $\left(26 \mathrm{~cm}^{3}\right.$ vs. $\left.81 \mathrm{~cm}^{3}\right)$. This results in a very large volume of reversible electroporation and a much lower volume of irreversible electroporation $\left(0.9 \mathrm{~cm}^{3}\right)$. It is somewhat surprising that the perpendicular direction of the electric field produced better results, since the threshold for electroporation is higher in this direction and therefore lower volumes would be expected. This can be explained by a much higher current that is generated by the field parallel to muscle fiber direction (conductivity is higher in that direction), thus the limitation for electric current $(30 \mathrm{~A})$ set in the objective function are exceeded earlier for the parallel direction.

The optimization results for six electrodes are presented in Figure 9. In this case, the perpendicular orientation produced almost two times better results than the parallel orientation. Similarly as for two electrodes, the sequence of images in Figure 9 shows, how taking into account the changes in conductivity during electroporation increases

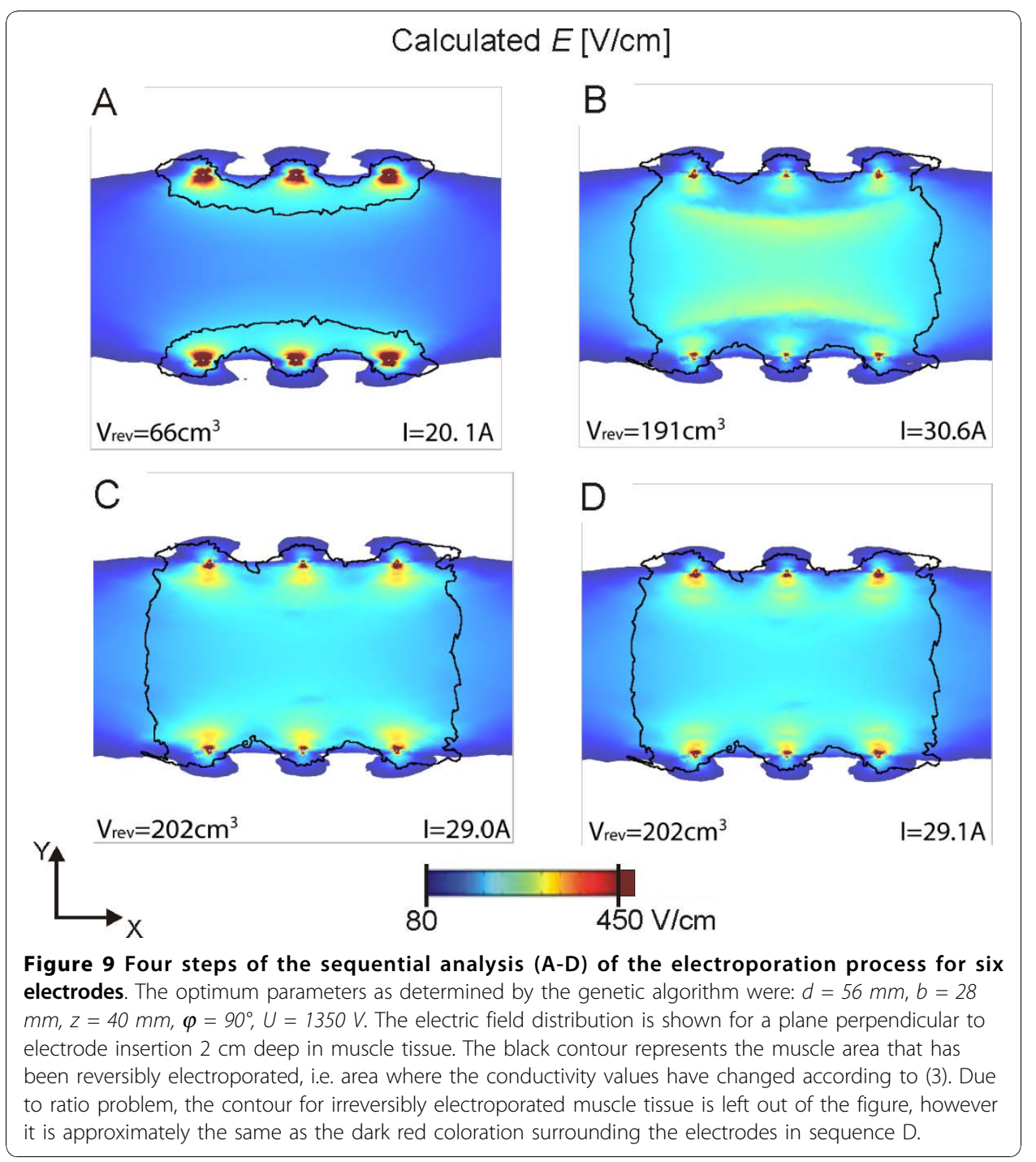




\section{Calculated $E[\mathrm{~V} / \mathrm{cm}]$}

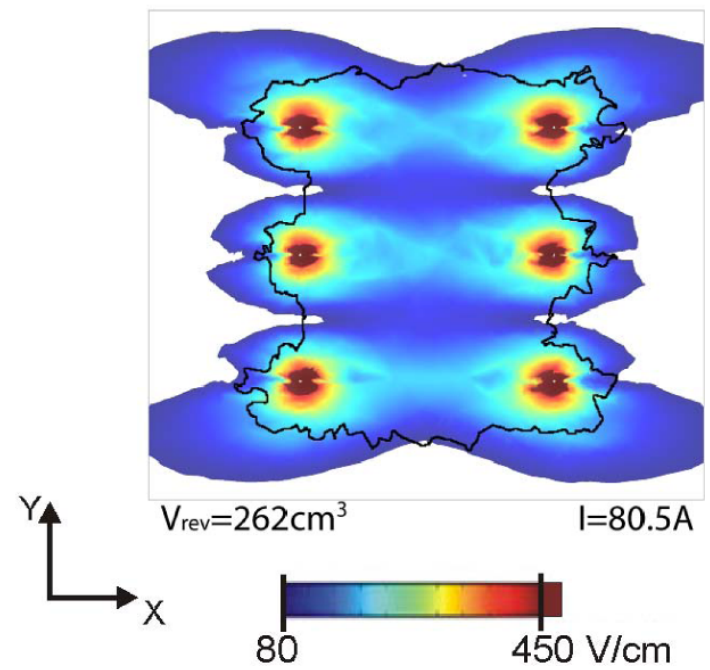

Figure 10 The last step of the sequential analysis of the electroporation process for six electrodes The same parameters as in Figure 9 were used, except for $\varphi=0^{\circ}$. The electric field distribution is shown for a plane perpendicular to electrode insertion $2 \mathrm{~cm}$ deep in muscle tissue. The black contour represents the muscle area that has been reversibly electroporated, i.e. area where the conductivity values have changed according to (3). Due to ratio problem, the contour for irreversibly electroporated muscle tissue is left out of the figure; however it is approximately the same as the dark red coloration surrounding the electrodes.

the calculated volumes of reversible electroporation. When analyzing how $V_{\text {rev }}$ increases with consecutive steps we obtained that it is a highly non-linear function where in the first step the biggest increase occurs; for two electrodes the increase is 2.5 times after the first step and 3.1 times at the final sequence; for six electrodes the increase in $V_{\text {rev }}$ after the first step is 2.9 times and 3.1 at the end of the sequence. The changes in $V_{i r r}$ are negligible due to limitation of $V_{i r r}<1 \mathrm{~cm}^{3}$.

The difference between the perpendicular and parallel orientation can be illustrated by using the same parameters as determined for optimal solution shown in Figure 9, but by changing the direction of the generated electric field so that it is aligned with muscle fibers $\left(\varphi=0^{\circ}\right)$. In this case, even more muscle volume becomes reversibly electroporated, however at the same time, the current flowing through the tissue $(80.5 \mathrm{~A})$ is much higher than the allowed current $(30 \mathrm{~A})$ and also much higher compared to the current for the perpendicular orientation (29.1 A). Also approximately three times more tissue is irreversibly electroporated for parallel compared to perpendicular orientation (Figure 10).

\section{Discussion}

Gene electrotransfer is already successfully being used for pDNA delivery in clinical applications, such as gene therapy and DNA vaccination. However, achieving an adequate extent of electroporation in target tissues can be difficult and requires extensive experimentation. Numerical modeling of electroporation can be used to complement in vivo experimentation as it allows planning of the electric field distribution beforehand. In this study we used 3D numerical modeling of muscle tissue, parameterization 
and numerical optimization to determine the affects of different geometrical and electrical parameters on the distribution of electric field in muscle tissue and the optimum parameters for gene electrotransfer in muscle tissue.

In the first part of this work we performed a parametric study to determine how various parameters affect the electric field distribution and volumes of tissue exposed to only reversible electric fields in muscle tissue, which is a prerequisite for effective gene electrotransfer. We determined that for large distances between the electrodes $(d)$ and for placing the electrodes deeper into the muscle $(z)$, the volumes of reversibly electroporated tissue $\left(V_{\text {rev }}\right)$ increases. However, concurrently the volume of irreversibly electroporated tissue $\left(V_{i r r}\right)$ and total current through the tissue $(I)$ also increase (see Tables 1 and 2, and Figures 4 and 6). Increases in $V_{i r r}$ and $I$ can be explained with higher voltage needed to reach the optimal electric field distribution at given $d$ (Figures $4 \mathrm{a}$ and 6a), while for deeper insertion (larger $z$ ) $V_{i r r}$ and $I$ increase due to a larger surface area of the electrodes in the tissue. For two electrodes the limiting factor is $V_{i r}$, which increases over the limit of $1 \mathrm{~cm}^{3}$ if voltage over $1600 \mathrm{~V}$ is used. For six electrodes $I$ increases over 30 A before $V_{i r r}$ gets over $1 \mathrm{~cm}^{3}$ and $I$ can therefore be considered the limiting factor. Obviously, by choosing a different objective functions with different limit for $V_{i r r}$ and $I$ it is possible to control their importance and thereby adjust the results accordingly to the application and equipment used. The distance between the electrodes in a row $(b)$ for six electrodes does not have much effect on $V_{\text {rev }}$ or $V_{i r}$, except at very small distances $b$, which, as expected is not optimal since three electrodes with the same electric potential positioned very closely produce an electric field very similar to the one of only one electrode. The advantages of having several electrodes are therefore lost at small distances $b$.

When analyzing the effect of electrode orientation with respect to muscle fibers, we obtained that the perpendicular orientation of the electrodes $\left(\varphi=90^{\circ}\right)$ is better than for the parallel orientation $\left(\varphi=0^{\circ}\right)$ (Tables 1 and 2), since coverage of larger volumes of tissue with electric field above $E_{r e v}$ and below $E_{i r r}$ can be obtained. This can be mostly explained by the smaller volumes of irreversible electroporation achieved in the perpendicular orientation, while at the same time the current (I) flowing along the muscle fibers in the parallel orientations is much higher, therefore the current limitation of the objective function is achieved for lower voltages in the parallel orientation. The perpendicular orientation is significantly better for six needle electrodes $\left(F_{\perp} \approx 2 \times\right.$ $\left.F_{||}\right)$while for two needle electrodes the difference is not that large (20\%). This is in agreement with the in vivo study in mice, where no statistical difference in gene expression was obtained between the perpendicular and parallel orientation for two needle electrodes [34]. If possible, however, it is best to switch orientation of the electric field during the application of electric pulses for more effective gene electrotransfer, as already shown in several studies $[46,77,78]$.

Furthermore, we analyzed the voltage dependence of the optimal solutions $F(U)$ in parallel with the volume of irreversibly electroporated tissue $V_{i r r}(U)$. We obtained that by increasing the applied voltage the volume of only reversibly electroporated tissue increased until an optimal voltage for a given electrode configuration was achieved (Figures 5 and 7). A further increase in the applied voltage lead to excessive tissue damage (large $V_{i r r}$ ) and sharp decrease in the objective function value $F$. This strong dependency on pulse amplitude and relatively narrow window of pulse amplitudes for 
optimal treatment is in accordance with experimental observations [36,58,71,79], where similarly transfection efficiency gradually increased above a threshold voltage, but further increase in voltage lead to a decrease in transfection.

When the results of the parametric study are examined in details, some surprising results can be seen. The relationship between the maximum objective function value and different parameters is not always a smooth curve (e.g. Figure 6b). This is due to an error introduced by relatively large discretization steps: as the objective functions were only evaluated for discrete values of the analyzed parameters some good solutions were missed. The discretization error is also responsible for a "strange" result for $\mathrm{d}=56 \mathrm{~mm}$, where in contrast to all other best solutions the parallel orientation produced better results than the perpendicular orientation. Also, for small distances $d$ between the electrodes, $I$ becomes the major limiting factor and therefore $V_{i r r}$ does not come even close to the limiting value of $1 \mathrm{~cm}^{3}$ set in the objective function. The reason for this seems to be in the extreme non-linearity of the used model. Namely, for smaller electrode distances the electric currents get very high due to small resistance between the electrodes.

The parametric analysis enabled us to understand the relationship between different parameters that can affect the electric field distribution and thus gene electrotransfer. However, in order to optimize these parameters for a given clinical application (treatment planning) such an exhaustive search of the parameter space would take too long and demands very large computer resources. A better approach is, as already demonstrated for electrochemotherapy $[67,68]$ to directly apply an optimization algorithm to determine the optimal parameters. In our study, optimization took only 1.2 hours compared to 23 hours for the parametric study (for two electrodes) and 1.4 hours compared to 4 days for six electrodes. In our optimization study we used the same objective function as in the parametric study, only the parameter stepping was more accurate (see Methods). Therefore, as expected the obtained optimal solutions differ only slightly from the ones obtained in the parametric study (compare Figures 8 and 9 with Tables 1 and 2). This difference can be attributed to a smaller discretization step used in the optimization.

The electric field distributions of the optimal solutions are presented in Figure 8 (two electrodes) and Figure 9 (six electrodes). It can be seen that taking into account dynamic changes of conductivity during electroporation (sequential analysis) has a substantial effect on the final electric field distribution and $V_{r e v}$. Namely, in the first sequence only a small volume of muscle tissue is reversibly electroporated; while in the final sequence the whole volume between the electrodes reaches $E>E_{r e v}$ (compare Figures $8 \mathrm{a}, \mathrm{b}, \mathrm{c}$ and $8 \mathrm{~d}$ ). This effect is more pronounced for six electrodes (Figures 9a, b, $c$ and $9 d)$. An array of six electrodes also provides a better electric field distribution overall, with higher objective function values $\left(F_{6} \approx 3 \times F_{2}\right)$. These results agree with our previous studies of optimization for electrochemotherapy $[59,66]$ that more electrodes enable coverage of larger volumes of tissue with a more homogeneous field. Six electrodes probably represent a good compromise between optimal electric field distributions and still keeping the invasiveness of the procedure relatively low. Nevertheless, using two electrodes can also produce good results, if parameters are select appropriately as already demonstrated $[34,80,81]$.

The objective function used in our study was chosen according to the prerequisite for efficient gene electrotransfer: the cells should only be electroporated reversibly and 
not irreversibly. Our choice of objective function is also based on the experimental observation that the volume of electrotransfected muscle tissue correlates with the amount of expressed protein [45]. In several studies of gene electrotransfer it was shown that larger transfected volumes are beneficial while for DNA vaccination the transfected volume is probably not such a critical parameter [19]. The optimization and proper selection of objective function has to be done for a specific application together with researchers and physicians in clinics, based on complementary analysis and evaluation of pain and other undesired effects, such as tissue inflammation or thermal damage.

The presented analysis is partially similar to previous studies of optimization of parameters for electrochemotherapy [66-68] or irreversible ablation of tumors (IRE) [61,63] where parameterization and/or optimization was also used to determine optimal electroporation parameters. However, there are two very important differences between our and the previous studies of ECT and IRE. Firstly, we included muscle anisotropy and sequential analysis in our models which was never done before and has also important effect on optimal solutions. Secondly, for ECT the objective function is set so that the most important parameter (weight) is the coverage of the whole tumor with $E>E_{r e v}$, while irreversible electroporation of the tumor is not severely penalized, since the goal of the therapy is tumor death; in EGT, however, it is enough that target tissue is just above the reversible electroporation threshold, while irreversible electroporation is not acceptable since it does not lead to expression of transfected genes. For this reason the additional constrain of $V_{i r}$ was put into the objective function, which penalizes solutions that would damage the tissue. For IRE a similarly reasoning would lead to another choice of objective function. Another important difference between the three applications is also what we want to treat: in ECT and IRE we want to treat a well defined target tissue and avoidance of electroporating vital organs is crucial, while for EGT of muscle tissue we want to reversibly electroporate large volumes.

In our numerical models joule heating was not analyzed as several studies have already shown that heating due to short $100 \mu$ s is negligible $[82,83]$. Nevertheless, a conservative estimation of the temperature after the electric pulses (see Figure 9 for parameters used), where cooling of tissue due to heat conduction was not taken into account, was below $46{ }^{\circ} \mathrm{C}$ in the vicinity of the electrodes and below $38^{\circ} \mathrm{C}$ in the center between the electrodes, confirming that the proposed pulses would not cause extensive thermal damage. Furthermore, in our case the $30 \mathrm{~A}$ limit for total current prevented unwanted thermal damage. However, if longer trains of pulses were applied, e.g. $8 \times 10$ $\mathrm{ms}$, thermal damage could become a the limiting factor that would have to be taken into account in the objective function.

We analyzed two and six needle electrode configurations, while plate electrodes were not analyzed since they cannot be applied for gene electrotransfer into muscle tissue in large animals and humans $[84,85]$. Two needle electrodes were analyzed since they are widely used in in vivo gene electrotransfer, while six electrodes were chosen as they enable a more homogeneous electric field inside treated tissue and altogether more optimal solutions. The relatively large electrode distances used in the study were used to extent applicability of our results from small animals to large animals and humans.

One of the limitations of our numerical model is that it performs calculations on a limited domain of muscle tissue and that no other tissues (e.g. skin) are included. This 
is justified since we checked how the size of our model and boundaries affect the final results. No significant variation of the results (less than 2\%) was obtained if the size of the model was increased for a factor of two. Also we have previously shown that if an additional layer with much lower conductivity is added on the top surface (resembling skin tissue) no significant effect is observed on the electric field distribution [66].

We further have to stress that the presented model and optimization was performed for relatively short electric pulses $(8 \times 100 \mu \mathrm{s})$ since the thresholds $E_{r e v}$ and $E_{i r r}$ are relatively well defined [72]. In a variety of studies of in vivo gene electrotransfer it was shown that different electric pulse parameters can be used for efficient transfection [32]: 1) relatively short pulses of $6 \times 100 \mu$ s [86]; 2) relatively long and low pulses, e.g. $8 \times 20 \mathrm{~ms}$ [35,80,87-89]; and 3) combination of high-voltage and low-voltage pulses [47,71,90-93]. To use the presented numerical optimization for different pulses, the electroporation thresholds would have to be determined and built into the electroporation models. The presented method of numerical modeling and optimization is generic and can be applied to different electrode configurations (e.g. plate, hexagonal, multiarray), electric pulse parameters (if thresholds $E_{r e v}$ and $E_{i r r}$ are known), other tissues (skin, liver, etc.) or performed for different definition of objective function defined on the basis of specific needs of given electroporation-based clinical applications such as gene therapy, DNA vaccination, electrochemotherapy or ablation by irreversible electroporation.

The presented numerical study of gene electrotransfer is the first study that enables optimization of electric parameters and electrode positions for gene electrotransfer in vivo. Moreover, it takes into account anisotropy of muscle tissue as well as dynamic changes of conductivity during electroporation by using sequential analysis. As such, it presents the first attempt to optimize electric pulse parameters and electrode positioning for gene electrotransfer. Our results can be used as guidelines for researchers and physicians in selecting optimal parameters for in vivo gene electrotransfer and thus indirectly also reduce the number of animals used in clinical studies of gene therapy and DNA vaccination.

\section{Acknowledgements}

The presented work was supported by several grants of the Slovenian Research Agency (ARRS).

\section{Authors' contributions}

$A Z, D M$ and MP were involved in the design of the study. AZ, SC and MP built the numerical model. AZ performed the parametric study and optimization. AZ and MP performed the data analysis. All authors were involved in the preparing of and have approved the final manuscript.

\section{Competing interests}

The authors declare that they have no competing interests.

Received: 3 September 2010 Accepted: 4 November 2010 Published: 4 November 2010

References

1. Cavazzana-Calvo M, Hacein-Bey S, Basile G, Dupuis-Girod S, Thrasher A, Wulffraat N, Sorensen R, Casanova J, Le Deist F, Fischer A: Gene therapy of human severe combined immunodeficiency (SCID)-X1 disease. Blood 2000, 96:2533.

2. Hacein-Bey-Abina S, Von Kalle C, Schmidt M, McCormack MP, Wulffraat N, Leboulch P, Lim A, Osborne CS, Pawliuk R, Morillon E, Sorensen R, Forster A, Fraser P, Cohen Il, de Saint Basile G, Alexander I, Wintergerst U, Frebourg T, Aurias A, Stoppa-Lyonnet D, Romana S, Radford-Weiss I, Gross F, Valensi F, Delabesse E, Macintyre E, Sigaux F, Soulier J, Leiva LE, Wissler M, Prinz C, Rabbitts TH, Le Deist F, Fischer A, Cavazzana-Calvo M: LMO2-Associated Clonal T Cell Proliferation in Two Patients after Gene Therapy for SCID-X1. Science 2003, 302:415-419.

3. Mitsuyasu RT, Merigan TC, Carr A, Zack JA, Winters MA, Workman C, Bloch M, Lalezari J, Becker S, Thornton L, Akil B, Khanlou H, Finlayson R, McFarlane R, Smith DE, Garsia R, Ma D, Law M, Murray JM, von Kalle C, Ely JA, Patino SM, 
Knop AE, Wong P, Todd AV, Haughton M, Fuery C, Macpherson JL, Symonds GP, Evans LA, Pond SM, Cooper DA: Phase 2 gene therapy trial of an anti-HIV ribozyme in autologous CD34+ cells. Nat Med 2009, 15:285-292.

4. Luxembourg A, Evans C, Hannaman D: Electroporation-based DNA immunisation: translation to the clinic. Expet Opin Biol Ther 2007, 7:1647-1664.

5. Stevenson FK, Ottensmeier CH, Rice J: DNA vaccines against cancer come of age. Curr Opin Immunol 2010, 22:264-270.

6. van Drunen Littel-van den Hurk S, Hannaman D: Electroporation for DNA immunization: clinical application. Expert Rev Vaccines 2010, 9:503-517.

7. Prud'homme GJ, Glinka Y, Khan AS, Draghia-Akli R, others: Electroporation-enhanced nonviral gene transfer for the prevention or treatment of immunological, endocrine and neoplastic diseases. Curr Gene Ther 2006, 6:243.

8. Sersa G, Cemazar M, Miklavcic D: Antitumor effectiveness of electrochemotherapy with cisdiamminedichloroplatinum(ii) in mice. Cancer Res 1995, 55:3450-3455.

9. Cavazzana-Calvo M, Thrasher A, Mavilio F: The future of gene therapy. Nature 2004, 427:779-781.

10. Cemazar M, Golzio M, Sersa G, Hojman P, Kranjc S, Mesojednik S, Rols MP, Teissie J: Control by pulse parameters of DNA electrotransfer into solid tumors in mice. Gene Ther 2009, 16:635-644.

11. Karmali PP, Chaudhuri A: Cationic liposomes as non-viral carriers of gene medicines: Resolved issues, open questions, and future promises. Med Res Rev 2007, 27:696-722.

12. Parker AL, Newman C, Briggs S, Seymour L, Sheridan PJ: Nonviral Gene Delivery: Techniques and Implications for Molecular Medicine. Expert Rev Mol Med 2003, 5:1-15.

13. Ferber D: Gene therapy: Safer and virus-free? Science 2001, 294:1638-1642.

14. Lehrman S: Virus treatment questioned after gene therapy death. Nature 1999, 401:517-518

15. Mir LM: Therapeutic perspectives of in vivo cell electropermeabilization. Bioelectrochemistry 2001, 53:1-10.

16. Somiari S, Glasspool-Malone J, Drabick JJ, Gilbert RA, Heller R, Jaroszeski MJ, Malone RW: Theory and in vivo application of electroporative gene delivery. Mol Ther 2000, 2:178-187.

17. Gehl J: Electroporation for drug and gene delivery in the clinic: doctors go electric. Meth Mol Biol 2008, 423:351.

18. Daud A, DeConti R, Andrews S, Urbas P, Riker A, Sondak V, Munster P, Sullivan D, Ugen K, Messina J, Heller R: Phase I Trial of Interleukin-12 Plasmid Electroporation in Patients With Metastatic Melanoma. J Clin Oncol 2008, 26:5896-5903.

19. Hojman P: Basic Principles and Clinical Advancements of Muscle Electrotransfer. Curr Gene Ther 2010, 10:128-138

20. Andre F, Mir LM: DNA electrotransfer: its principles and an updated review of its therapeutic applications. Gene Ther 2004, 11:S33-S42

21. Favard C, Dean DS, Rols MP: Electrotransfer as a non viral method of gene delivery. Curr Gene Ther 2007, 7:67-77

22. Brown PA, Bodles-Brakhop AM, Pope MA, Draghia-Akli R: Gene therapy by electroporation for the treatment of chronic renal failure in companion animals. BMC Biotechnol 2009, 9:4.

23. Rice J, Ottensmeier $\mathrm{CH}$, Stevenson FK: DNA vaccines: precision tools for activating effective immunity against cancer. Nat Rev Cancer 2008, 8:108-120.

24. Bodles-Brakhop AM, Draghia-Akli R: DNA vaccination and gene therapy: optimization and delivery for cancer therapy. Expet Rev Vaccine 2008, 7:1085-1101.

25. Neumann E, Schaeferridder M, Wang Y, Hofschneider PH: Gene-transfer into mouse lyoma cells by electroporation in high electric-fields. Embo Journal 1982, 1:841-845.

26. Golzio M, Teissie J, Rols MP: Direct visualization at the single-cell level of electrically mediated gene delivery. Proc Natl Acad Sci USA 2002, 99:1292-1297.

27. Pavlin M, Flisar K, Kandušer M: The Role of Electrophoresis in Gene Electrotransfer. J Membrane Biol 2010, , 236: 75-79.

28. Faurie C, Rebersek M, Golzio M, Kanduser M, Escoffre J, Pavlin M, Teissie J, Miklavcic D, Rols M: Electro-mediated gene transfer and expression are controlled by the life-time of DNA/membrane complex formation. J Gene Med 2010, 12:117-125.

29. Kanduser M, Miklavcic D, Pavlin M: Mechanisms involved in gene electrotransfer using high- and low-voltage pulses - An in vitro study. Bioelectrochemistry 2009, 74:265-271.

30. Cemazar M, Sersa G: Electrotransfer of therapeutic molecules into tissues. Curr Opin Mol Ther 2007, 9:554-562.

31. Escoffre J, Portet T, Wasungu L, Teissie J, Dean D, Rols M: What is (Still not) Known of the Mechanism by Which Electroporation Mediates Gene Transfer and Expression in Cells and Tissues. Mol Biotechnol 2009, 41:286-295.

32. Gehl J: Electroporation: theory and methods, perspectives for drug delivery, gene therapy and research. Acta Physiol Scand 2003, 177:437-447.

33. Gilbert RA, Jaroszeski MJ, Heller R: Novel electrode designs for electrochemotherapy. Biochim Biophys Acta Gen Subj 1997, 1334:9-14

34. Aihara H, Miyazaki J: Gene transfer into muscle by electroporation in vivo. Nat Biotechnol 1998, 16:867-870.

35. Rols MP, Delteil C, Golzio M, Dumond P, Cros S, Teissie J: In vivo electrically mediated protein and gene transfer in murine melanoma. Nat Biotechnol 1998, 16:168-171.

36. Suzuki T, Shin B, Fujikura K, Matsuzaki T, Takata K: Direct gene transfer into rat liver cells by in vivo electroporation. FEBS Lett 1998, 425:436-440

37. Mir L, Bureau M, Rangara R, Schwartz B, Scherman D: Long-term, high level in vivo gene expression after electric pulse-mediated gene transfer into skeletal muscle. Compt Rendus Acad Sci III Sci Vie 1998, 321:893-899.

38. Heller R, Deconti R, Messina J, Andrews S, Urbas P, Ugen K, Puleo C, Sondak V, Riker A, Daud A: Gene therapy with plasmid IL-12 delivered by electroporation in patients with malignant melanoma: results of first human Phase I trial. EJC Supplements 2006, 4:106-106.

39. Gothelf A, Eriksen J, Hojman P, Gehl J: Duration and level of transgene expression after gene electrotransfer to skin in mice. Gene Ther 2010, 17:839-845

40. Liu F, Heston S, Shollenberger LM, Sun B, Mickle M, Lovell M, Huang L: Mechanism of in vivo DNA transport into cells by etectroporation: etectrophoresis across the plasma membrane may not be involved. J Gene Med 2006, 8:353-361. 
41. Low L, Mander A, McCann K, Dearnaley D, Tjelle T, Mathiesen I, Stevenson F, Ottensmeier C: DNA Vaccination with Electroporation Induces Increased Antibody Responses in Patients with Prostate Cancer. Hum Gene Ther 2009, 20:1269-1278.

42. Sallberg M, Frelin L, Diepolder H, Jung M, Mathiesen I, Fons M, Hultcrantz R, Carlsson T, Weiland O: A first clinical trial of therapeutic vaccination using naked dna delivered by in vivo electroporation shows antiviral effects in patients with chronic hepatitis c. J Hepatol 2009, 50:43.

43. Heller L, Heller R: Electroporation Gene Therapy Preclinical and Clinical Trials for Melanoma. Curr Gene Ther 2010 10:312-317.

44. Mignet N, Vandermeulen G, Pembouong G, Largeau C, Thompson B, Spanedda M, Wasungu L, Rols M, Bessodes M, Bureau MF, Préat V, Scherman D: Cationic and anionic lipoplexes inhibit gene transfection by electroporation in vivo. J Gene Med 2010, 12:491-500.

45. Bureau MF, Jugé L, Seguin J, Rager M, Scherman D, Mignet N: Muscle transfection and permeabilization induced by electrotransfer or pluronic ${ }^{\oplus}$ L64Paired study by optical imaging and MRI. Biochim Biophys Acta Gen Subj 2010, 1800:537-543.

46. Heller R, Cruz Y, Heller LC, Gilbert RA, Jaroszeski MJ: Electrically Mediated Delivery of Plasmid DNA to the Skin, Using a Multielectrode Array. Hum Gene Ther 2010, 21:357-362.

47. Pavselj N, Preat V: DNA electrotransfer into the skin using a combination of one high- and one low-voltage pulse. $J$ Contr Release 2005, 106:407-415.

48. Heller LC, Jaroszeski MJ, Coppola D, McCray AN, Hickey J, Heller R: Optimization of cutaneous electrically mediated plasmid DNA delivery using novel electrode. Gene Ther 2006, 14:275-280.

49. Vandermeulen G, Staes E, Vanderhaeghen ML, Bureau MF, Scherman D, Préat V: Optimisation of intradermal DNA electrotransfer for immunisation. J Contr Release 2007, 124:81-87.

50. Roos A, Eriksson F, Walters DC, Pisa P, King AD: Optimization of Skin Electroporation in Mice to Increase Tolerability of DNA Vaccine Delivery to Patients. Mol Ther 2009, 17:1637-1642.

51. Mathiesen I: Electropermeabilization of skeletal muscle enhances gene transfer in vivo. Gene Ther 1999, 6:508-514

52. Satkauskas S, Andre F, Bureau MF, Scherman D, Miklavcic D, Mir LM: Electrophoretic component of electric pulses determines the efficacy of In Vivo DNA electrotransfer. Hum Gene Ther 2005, 16:1194-1201.

53. Hojman P, Zibert JR, Gissel H, Eriksen J, Gehl J: Gene expression profiles in skeletal muscle after gene electrotransfer. BMC Mol Biol 2007, 8.

54. Schertzer JD, Plant DR, Lynch GS: Optimizing plasmid-based gene transfer for investigating skeletal muscle structure and function. Mol Ther 2006, 13:795-803

55. Andre FM, Gehl J, Sersa G, Preat V, Hojman P, Eriksen J, Golzio M, Cemazar M, Pavselj N, Rols MP, Miklavcic D, Neumann E, Teissie J, Mir LM: Efficiency of High- and Low-Voltage Pulse Combinations for Gene Electrotransfer in Muscle, Liver, Tumor, and Skin. Hum Gene Ther 2008, 19:1261-1271.

56. Miyazaki S, Miyazaki Jl: In vivo DNA electrotransfer into muscle. Dev Growth Differ 2008, 50:479-483.

57. Sel D, Cukjati D, Batiuskaite D, Slivnik T, Mir LM, Miklavcic D: Sequential finite element model of tissue electropermeabilization. IEEE Trans Biomed Eng 2005, 52:816-827.

58. Gehl J, Sorensen TH, Nielsen K, Raskmark P, Nielsen SL, Skovsgaard T, Mir LM: In vivo electroporation of skeletal muscle: threshold, efficacy and relation to electric field distribution. Biochim Biophys Acta Gen Subj 1999, 1428:233-240.

59. Corovic S, Pavlin M, Miklavcic D: Analytical and numerical quantification and comparison of the local electric field in the tissue for different electrode configurations. Biomedical Engineering Online 2007, 6.

60. Miklavcic D, Semrov D, Mekid H, Mir LM: A validated model of in vivo electric field distribution in tissues for electrochemotherapy and for DNA electrotransfer for gene therapy. Biochim Biophys Acta Gen Subj 2000, 1523:73-83.

61. Edd JF, Davalos RV: Mathematical Modeling of irreversible Electroporation for treatment planning. Technol Cancer Res Treat 2007, 6:275-286.

62. Semrov D, Miklavcic D: Calculation of the electrical parameters in electrochemotherapy of solid tumours in mice. Comput Biol Med 1998, 28:439-448.

63. Garcia PA, Rossmeisl JH, Neal RE, Ellis TL, Olson JD, Henao-Guerrero N, Robertson J, Davalos RV: Intracranial nonthermal irreversible electroporation: in vivo analysis. J Memb Biol 2010, 236:127-136.

64. Miklavcic D, Beravs K, Semrov D, Cemazar M, Demsar F, Sersa G: The importance of electric field distribution for effective in vivo electroporation of tissues. Biophys J 1998, 74:2152-2158.

65. Zupanic A, Miklavcic D: Optimization and numerical modeling in irreversible electroporation treatment planning. Irreversible electroporation Berlin: Springer Berlin Heidelberg; 2010, 203-222.

66. Corovic S, Zupanic A, Miklavcic D: Numerical modeling and optimization of electric field distribution in subcutaneous tumor treated with electrochemotherapy using needle electrodes. IEEE Trans Plasma Sci 2008, 36:1665-1672.

67. Zupanic A, Corovic S, Miklavcic D: Optimization of electrode position and electric pulse amplitude in electrochemotherapy. Radiol Oncol 2008, 42:93-101.

68. Miklavcic D, Snoj M, Zupanic A, Kos B, Cemazar M, Kropivnik M, Bracko M, Pecnik T, Gadzijev E, Sersa G: Towards treatment planning and treatment of deep-seated solid tumors by electrochemotherapy. Biomedical Engineering Online 2010, 9:8.

69. Mir LM, Bureau MF, Gehl J, Rangara R, Rouy D, Caillaud JM, Delaere P, Branellec D, Schwartz B, Scherman D: Highefficiency gene transfer into skeletal muscle mediated by electric pulses. Proc Natl Acad Sci USA 1999, 96:4262-4267.

70. Bureau MF, Gehl J, Deleuze V, Mir LM, Scherman D: Importance of association between permeabilization and electrophoretic forces for intramuscular DNA electrotransfer. Biochim Biophys Acta Gen Subj 2000, 1474:353-359.

71. Corovic S, Zupanic A, Kranjc S, Al Sakere B, Leroy-Willig A, Mir LM, Miklavcic D: The influence of skeletal muscle anisotropy on electroporation: in vivo study and numerical modeling. Med Biol Eng Comput 2010, 48:637-648.

72. Cukjati D, Batiuskaite $D$, Andre F, Miklavcic D, Mir LM: Real time electroporation control for accurate and safe in vivo non-viral gene therapy. Bioelectrochemistry 2007, 70:501-507.

73. Pavselj N, Bregar Z, Cukjati D, Batiuskaite D, Mir LM, Miklavcic D: The course of tissue permeabilization studied on a mathematical model of a subcutaneous tumor in small animals. IEEE Trans Biomed Eng 2005, 52:1373-1381. 
74. Gabriel C, Peyman A, Grant EH: Electrical conductivity of tissue at frequencies below $1 \mathrm{MHz}$. Phys Med Biol 2009, 54:4863-4878.

75. Ivorra A, Al-Sakere B, Rubinsky B, Mir LM: Tumor conductivity during electroporation. Phys Med Biol 2009, 54:5949-5963.

76. Ivorra A, Al-Sakere B, Rubinsky B, Mir LM: In vivo electrical conductivity measurements during and after tumor electroporation: conductivity changes reflect the treatment outcome. Phys Med Biol 2009, 54:5949-5963.

77. Rebersek M, Faurie C, Kanduser M, Xorovic S, Teissie J, Rols MP, Miklavcic D: Electroporator with automatic change of electric field direction improves gene electrotransfer in-vitro. Biomedical Engineering Online 2007, 6.

78. Faurie U, Phez E, Golzio M, Vossen C, Lesbordes JC, Delteil C, Teissie J, Rols MP: Effect of electric field vectoriality on electrically mediated gene delivery in mammalian cells. Biochim Biophys Acta Biomembr 2004, 1665:92-100.

79. Gehl J, Rangara R, Rouy D, Caillaud JM, Delaere P, Branellec D, Schwartz B, Scherman D: High-Efficiency Gene Transfer into Skeletal Muscle Mediated by Electric Pulses. Proc Natl Acad Sci USA 1999, 4262-4267.

80. Scheerlinck JPY, Karlis J, Tjelle TE, Presidente PJA, Mathiesen I, Newton SE: In vivo electroporation improves immune responses to DNA vaccination in sheep. Vaccine 2004, 22:1820-1825.

81. Wu CJ, Lee SC, Huang HW, Tao MH: In vivo electroporation of skeletal muscles increases the efficacy of Japanese encephalitis virus DNA vaccine. Vaccine 2004, 22:1457-1464.

82. Lackovic I, Magjarevic R, Miklavcic D: Three-dimensional finite-element analysis of Joule heating in electrochemotherapy and in vivo gene electrotransfer. IEEE Trans Diel Elec Insul 2009, 16:1338-1347.

83. Shafiee H, Garcia PA, Davalos RV: A Preliminary Study to Delineate Irreversible Electroporation From Thermal Damage Using the Arrhenius Equationa. J Biomech Eng Trans ASME 2009, 131:5.

84. Reed SD, Li S: Electroporation Advances in Large Animals. Current gene therapy 2009, 9:316-326.

85. Khan AS, Smith LC, Abruzzese RV, Cummings KK, Pope MA, Brown PA, Draghia-Akli R: Optimization of electroporation parameters for the intramuscular delivery of plasmids in pigs. DNA Cell Biol 2003, 22:807-814.

86. Heller R, Jaroszeski M, Atkin A, Moradpour D, Gilbert R, Wands J, Nicolau C: In vivo gene electroinjection and expression in rat liver. FEBS Lett 1996, 389:225-228.

87. Terada Y, Tanaka H, Okado T, Inoshita S, Kuwahara M, Akiba T, Sasaki S, Marumo F: Efficient and ligand-dependent regulated erythropoietin production by naked DNA injection and in vivo electroporation. Am J Kidney Dis 2001, 38 S50-S53.

88. Bettan M, Ivanov MA, Mir LM, Boissiere F, Delaere P, Scherman D: Efficient DNA electrotransfer into tumors. Bioelectrochemistry 2000, 52:83-90.

89. Ho S, Hahn W, Lee H, Kim D, Jeong J, Kim S, Yu SS, Jeon E, Kim S, Kim J: Protection against collagen-induced arthritis by electrotransfer of an expression plasmid for the interleukin-4. Biochem Biophys Res Comm 2004, 321:759-766.

90. Satkauskas S, Bureau MF, Puc M, Mahfoudi A, Scherman D, Miklavcic D, Mir LM: Mechanisms of in vivo DNA electrotransfer: Respective contributions of cell electropermeabilization and DNA electrophoresis. Mol Ther 2002, 5:133-140.

91. Tevz G, Pavlin D, Kamensek U, Kranjc S, Mesojednik S, Coer A, Sersa G, Cemazar M: Gene electrotransfer into murine skeletal muscle: A systematic analysis of parameters for long-term gene expression. Technol Cancer Res Treat 2008, 7:91-101.

92. Tevz G, Kranjc S, Cemazar M, Kamensek U, Coer A, Krzan M, Vidic S, Pavlin D, Sersa G: Controlled systemic release of interleukin-12 after gene electrotransfer to muscle for cancer gene therapy alone or in combination with ionizing radiation in murine sarcomas. J Gene Med 2009, 11:1125-1137.

93. Hojman P, Gissel H, Andre FM, Cournil-Henrionnet C, Eriksen J, Gehl J, Mir LM: Physiological Effects of High- and LowVoltage Pulse Combinations for Gene Electrotransfer in Muscle. Hum Gene Ther 2008, 19:1249-1260.

doi:10.1186/1475-925X-9-66

Cite this article as: Zupanic et al: Numerical optimization of gene electrotransfer into muscle tissue. BioMedical Engineering OnLine 2010 9:66.

\section{Submit your next manuscript to BioMed Central and take full advantage of:}

- Convenient online submission

- Thorough peer review

- No space constraints or color figure charges

- Immediate publication on acceptance

- Inclusion in PubMed, CAS, Scopus and Google Scholar

- Research which is freely available for redistribution 